\title{
The Use of Communication Technology By Pre-Service Science Teachers In The Scientific Process*
}

\author{
Nilgün YENİCE** \\ Neslihan YAVAŞOĞLU***
}

\author{
Fatma CANDARLI ARIKOZ ${ }^{* * *}$ \\ Gizem ALPAK TUNC ${ }^{* * * * *}$
}

\begin{abstract}
The aim of this study is to determinehow pre-service science teachers use information and communication technology in the scientific process. The study is a causal-comparative research. The participants were 190 pre-service science teachers attending a public university in the western region of Turkey during the academic year of 2017-2018. They were chosen using the conventional sampling technique. Concerning the use of the information and communication technologies in the scientific process by the participants the "Scale of the use of the information and communication technologies in the scientific process" (ICT) was administered. It was developed by Açıgül (2011) and consisted of 25 items. It can be stated that the participants employ the information and communication technologies for designing and conducting experiments, using the scientific process skills and in the scientific process. Based on the findings several suggestions weremade.
\end{abstract}

Keywords: Scientific process, Information and communication technology, preservice science teacher.

\footnotetext{
${ }^{*}$ This study is the developed version of the proceeding that made oral presentation at the V. International Eurasian Educational Research Congress held on 2-5 May 2018 at Akdeniz University.

** Orcid ID: https://orcid.org/0000-0002-7935-3110, Prof. Dr., Aydın Adnan Menderes University, Faculty of Education, Department of Mathematics and Science Education, nyenice@gmail.com

*** Orcid ID: https://orcid.org/0000-0002-3974-3739, Aydın Adnan Menderes University, Institute of Science, fatmacandarli@gmail.com

**** Orcid ID: https://orcid.org/0000-0001-9360-0715, Aydın Adnan Menderes University, Institute of Science, neslihanyvsgl@gmail.com

***** Orcid ID: https://orcid.org/0000-0002-9995-1134, Aydın Adnan Menderes University, Institute of Science, gizemalpak@windowslive.com
} 


\section{INTRODUCTION}

Nowadays significant developments in information and communication technologies facilitate access to scientific information, information storage and sharing. For this reason, the information that is quickly obtained loses its validity and is being replaced by new information. Thus, the new information obtained brings up new technologies. In addition, technology and knowledge constantly affect each other. With this dynamic relationship and rapid changes, 21st century individuals are living the information age (Demiralay, \& Karadeniz, 2010). In order for individuals to adapt to this era they should use information communication technologies effectively in scientific process. The technologies that enable the use and sharing of information include television, telephone, DVD, radio, satellite systems, computer hardware and software (UNESCO, 2006).

The innovative and ever-changing nature of the information and communication technologies (ICT) requires significant changes in educational systems, and many countries base their national education strategies on information and communication technologies. Educating individuals who can use information and communication technologies has become one of the requirements of the contemporary education. In Turkey the aim of the basic education program which was initiated in the school year of 2005-2006 is to enable all students to employ the information and communication technologies (MONE, 2006). In the educational program for the science courses which was put into implementation in the school year of 2017-2018 it is stated that the major skills for the 21. century should be emphasized, including skills of scientific process, life skills, innovative thinking skills, entrepreneurial thinking skills and skills of using information communication technologies (MONE, 2017). Integration of the teachinglearning process with the ICT has several advantages, including improving the student achievement, higher-level thinking and decision-making skills, critical thinking skills, research-related skills, motivation, the structuring of information processes and student attitudes towards courses. Therefore, it is reported that in recent period the integration of the ICT with the teaching-learning processes and the analysis of the ICT uses have been studied (Çavaş and Çavaş, 2005; Usluel, Mumcu and Demiraslan, 2007; Jang, 2009; Ersoy, \& Türkan, 2009).

In the General Competences Guide to Teaching Profession issued by the Ministry of National Education in 2006 it is stated that teachers should have several ICT skills. For instance, teachers should know the legal and moral responsibilities related to information and communication technologies and enable the students to acquire such responsibilities. They should be technology literate (i.e., they have the knowledge and skills of technology about the related concepts and practices). They should follow the developments in information and communication technologies. They should utilize information and communication technologies to support their professional development and increase productivity. They should use information and communication technologies (online magazines, package software, e-mails, etc.) to share information and offer appropriate learning environments for the students with different experiences, 
characteristics and abilities by using information and communication technologies. The course plans they develop should include how to use information and communication technologies in the course. They should use computers and other technological tools to prepare teaching and learning materials. They can access the resources related to learning and teaching in technological environments (databases, online resources, etc.) and evaluate their appropriateness. They should become a model for effective use of technology resources and teach them. They should analyze data using information and communication technologies. They should share information about the student evaluation with parents, school management and other educators by using information and communication technologies. Individuals in society try to understand the environment they live by using scientific process skills such as observation and research used by scientists. Therefore, individuals need to use and apply scientific process skills in their daily lives (Açıkgül, Firat, \& Özden, 2015). Technology contributes to science in these processes as an indispensable part of our daily life.

In order to use information communication technologies effectively in scientific process, individuals should have the necessary knowledge and skills (Cüre, \& Özdener, 2008). In order to acquire these knowledge and skills, individuals should be introduced to new technologies at early ages. There is a need for teachers who can effectively use information and communication technologies in educational environments and scientific processes for the creation and active use of new technologies. The ICT-related skills that teachers should have are reported as follows: being technology literate, using technology in courses, directing students to use technology, enabling the students to use the learning environment in the process of gaining the skills of accessing information and using information and collaborate with colleagues on the Internet for professional development and experience sharing (ISTE, 2000).

There are some studies dealing with the ability of in-service and pre-service teachers to employ the ICT skills (Eryılmaz, 2018); Albayrak Sarı, Canbazoğlu Bilici, Baran and Özbay (2016); Şad and Nalçacı (2015); Ural (2015); Demiraslan and Usluel (2005); Tor and Erden (2003); Hazzan (2000); Slough and Chamblee (2000)). For instance, Eryllmaz (2018) found that the undergraduate students attending the Faculty of Tourism had a sufficient level of the ICT skills at early years, but their skill level does not improve over time. It is reported that the skill level of individuals concerning the ICT varies based on several factors, including gender, grade level, type of high school and prior experience on the ICT training. Albayrak Sarı, Canbazoğlu Bilici, Baran and Özbay (2016) found a positive correlation between teachers' Technological Pedagogical Content Knowledge (TPCK) competency and their attitudes towards the ICT. They also concluded that the attitudes of the teachers with different subject matters towards the ICT do not significantly vary. Şad and Nalçacı (2015) concluded that the competency perceptions of the pre-service teachers about the use of the ICT are generally at a good level. However, it is also added that the competency perceptions of the pre-service English language, music and computer and instructional technology education teachers were sufficient in regard to the ICT. However, the competency perceptions of the pre-service mathematics 
and Turkish language teachers are found to be lower. Ural (2015) reported that teachers found it useful to use the ICT to increase student motivation, long-term learning and student interest and that their justification for not using the ICT was about time constraints, lack of necessary computers and Internet-related problems. Demiraslan and Usluel (2005) argued that a successful integration of the ICT into the learning and teaching process required those teachers who have necessary information and skills. Tor and Erden (2003) argued that utilizing technological opportunities in the information society depends to a great extent on the knowledge and skills of teachers in this regard. Teachers should benefit from technological opportunities in order to educate students according to the requirements of the information society, to enable students to learn more effectively and to update their information. Hazzan (2000) emphasized the fact that those teachers who employed technology in their own teaching activities have much more positive perceptions about technology. Slough and Chamblee (2000) found that teachers who realized the positive contribution of technology in their teaching activities did not refrain from resorting to the use of technology. These findings indicate that teachers should have experience and knowledge about technology integration. Given that science courses are designed for the creation of new scientific information and access to existing scientific knowledge and research these courses are related to information communication technologies and are an interactive field. Therefore, it is necessary for science teachers to be able to use information communication technologies effectively in their lessons and to have knowledge of communication technologies in order to be able to transfer the achievements about these fields to students. Considering the shortcomings stated in the literature and the skills highlighted in the general qualifications of the teacher profession it is thought that it will be useful and important to examine the state of pre-service science teachers using information communication technologies in scientific process in terms of different variables.

\section{Aim}

The fact that teachers and pre-service teachers have the skills of information communication technologies and that they can use these skills in the scientific process are seen as important in terms of preparing their students' learning environments to improve their knowledge and technology literacy skills and guiding their students in these environments. Therefore, the aim of this study is to determine how the pre-service science teachers use the information communication technologies in the scientific process.

\section{Problem statement}

The problem statement of the study is as follows: "How do pre-service science teacher use information communication technologies in scientific process and does it vary based on some variables?"

Based on it the study attempts to answer the following research questions: 
1. How does pre-service science teacher use information communication technologies in scientific process?

2. Do pre-service science teachers' use of the information communication technologies in scientific process vary based on

a. Gender, and

b. Purpose in using the information communication technologies?

\section{METHOD}

This research is of a causal comparison type. Such a research aims to determine the causes of an existing situation or event, the variables that influence these reasons, or the results of the effect (Büyüköztürk, Kılıç Çakmak, Akgün, Karadeniz, \& Demirel, 2012).

\section{Participants}

The participants of the study are pre-service science teachers attending a public university in the Western region of Turkey during the academic year of 2017-2018. The participants were identified using the convenience sampling (also known as availability sampling). It involves the selection of participants from available and eligible samples due to the financial, time or work constraints (Büyüköztürk et. al., 2012). Table 1 presents some characteristics of the participants.

Table 1.

Demographical characteristics of the participants

\begin{tabular}{lcccccccccc}
\hline & \multicolumn{2}{c}{1} & \multicolumn{2}{c}{2} & \multicolumn{2}{c}{3} & \multicolumn{2}{c}{4} & \multicolumn{2}{c}{ Total } \\
\cline { 2 - 11 } & $\mathrm{f}$ & $\%$ & $\mathrm{f}$ & $\%$ & $\mathrm{f}$ & $\%$ & $\mathrm{f}$ & $\%$ & $\mathrm{f}$ & $\%$ \\
\hline Female & 30 & 15.8 & 42 & 22.1 & 38 & 20.0 & 39 & 20.5 & 149 & 78.4 \\
Male & 9 & 4.7 & 10 & 5.3 & 11 & 5.8 & 11 & 5.8 & 41 & 21.6 \\
\hline Toplam & 39 & 20.5 & 52 & 27.4 & 49 & 25.8 & 50 & 26.3 & 190 & 100.0 \\
\hline
\end{tabular}

As can be seen in Table $178.4 \%$ of the participants were female ( $\mathrm{f}=149$ ) and $21.6 \%$ of them were male $(\mathrm{f}=41)$. Concerning grade levels, $20.5 \%$ are freshmen $(\mathrm{f}=39), 27.4 \%$ are sophomores ( $\mathrm{f}=52), 25.8 \%$ are juniors $(\mathrm{f}=49)$ and $26.3 \%$ are seniors $(\mathrm{f}=50)$. In Table 2 the reseasons for the use of the ICT by the participants are given: 
Tablo 2 .

The reasons for using the ICT

\begin{tabular}{|c|c|c|c|}
\hline Variables & Category & $\mathrm{N}$ & $\%$ \\
\hline \multirow{5}{*}{$\begin{array}{l}\text { Reasons for using } \\
\text { the ICT }\end{array}$} & Research & 36 & 18.9 \\
\hline & Social media use & 73 & 38.4 \\
\hline & Communication & 49 & 25.8 \\
\hline & Fun & 32 & 16.8 \\
\hline & Total & 190 & 100.0 \\
\hline
\end{tabular}

Table 2 indicates that $38.4 \%$ of the participants used the ICT for social media purposes $(\mathrm{N}=73), 25.8 \%$ for communication $(\mathrm{N}=49), 18.9 \%$ for research purposes $(\mathrm{N}=36)$ and $16.8 \%$ for fun $(\mathrm{N}=32)$.

\section{Data collection tools}

The data of the study were collected through a demographical form and a scale on the use of the ICT which was developed by Açıgül (2011) entitled the "Scale of the Information Communication Technologies in Scientific Process". It is a five-point likerttype scale consisted of twenty-five items. All statements are positively expressed. The scale has four sub-dimensions: the use of information, designing and implementing experiments, the use of scientific process skills and research and development. Table 3 presents the Cronbach alpha coefficients of the sub-dimensions of the scale in the original study and in the current study.

Table 3.

Cronbach alpha coefficients for the subdimensions of the scale

\begin{tabular}{lccc}
\hline Sub-dimensions & $\begin{array}{c}\text { Number of } \\
\text { items }\end{array}$ & $\begin{array}{c}\text { Cronbach Alpha } \\
\text { (Açlkgül (2011) }\end{array}$ & $\begin{array}{c}\text { Cronbach } \\
\text { Alpha in the } \\
\text { study }\end{array}$ \\
\hline 1. Information use & 7 & .87 & .85 \\
2. Design and implementation of & 7 & .89 & .85 \\
experiments & 7 & .87 & .83 \\
3. Scientific process skills & 4 & .75 & .78 \\
4. Research and development & 25 & .96 & .93 \\
Total & & & \\
\hline
\end{tabular}

The scores that are obtained from the scale are explained as follows (Yenilmez 2008; cited in Kara 2010): 
- Between 1.00 and 1.80: Never

- Between 1.81 and 2.60: Seldom

- $\quad$ Between 2.61 and 3.40: Sometimes

- $\quad$ Between 3.41 and 4.20: Frequent

- Between 4.21 and 5.00: Everytime

\section{Data analysis}

A statistical package program was used to analyze the data collected in the research. The descriptive statistics was used in order to determine the level of the use of the information communication technologies in science process by the participants based on the research problems. The scores of the participants were analysed using the normality test which indicated that the scores did not normally distribute $(\mathrm{p}<.05)$. In order to see whether or not the scores of the participants significantly vary based on gender the Mann Whitney U-Test was employed. In order to see whether or not the scores of the participants significantly vary based on the purpose of using the ICT the Kruskal Wallis H- Test was used.

\section{METHOD}

As stated above the first research question of the study is as follows: How do pre-service science teacher use information communication technologies in scientific process? In order to answer this question, the scores of the participants from the scale and its subdimensions are analysed to find out the arithmetical mean, standard deviation and minimum-maximum values. These are given in Table 4.

Table 4.

Descriptive statistics on the scores of the participants

\begin{tabular}{lccccc}
\hline Sub-dimensions & $\mathrm{N}$ & $\bar{X}$ & $\mathrm{~S}$ & Min & Max \\
\hline Using information & 190 & 4.29 & 0.56 & 2.57 & 5.00 \\
Designing and implementing & 190 & 3.64 & 0.72 & 1.43 & 5.00 \\
experiments & & & & & \\
Using Scientific Process Skills & 190 & 3.79 & 0.65 & 1.57 & 5.00 \\
Research and development & 190 & 4.35 & 0.54 & 2.75 & 5.00 \\
Total & 190 & 3.98 & 0.54 & 2.40 & 5.00 \\
\hline
\end{tabular}

As can be seen in Table 4 the mean score of the participants for the sub-dimension Using information is 4.29. It suggests that the participants always employ the ICT in using information. Their mean score for the sub-dimension of Research and development is 
found to be 4.35. It suggests that the participants always employ the ICT in the activities related to research and development. The mean scores of the participants in regard to the sub-dimensions Designing and implementing experiments and Using scientific process skills are 3.64 and 3.79, respectively. These findings indicate that the participants frequently make use of the ICT concerning the design and implementation of experiments and the scientific process skills.

The second research problem is about the effects of gender and the purpose of the use of the ICT on the participants' ability to employ the ICT. In order to see whether or not the scores of the participants significantly vary based on gender the Mann Whitney U-Test was employed. The results of the Mann Whitney U-Test are given in Table 5.

Table 5.

Results of the Mann Whitney U-Test

\begin{tabular}{|c|c|c|c|c|c|c|}
\hline & Gender & $\mathrm{N}$ & $\begin{array}{c}\text { Rank } \\
\text { average }\end{array}$ & Rank total & $\mathrm{U}$ & $\mathrm{p}$ \\
\hline \multirow[t]{2}{*}{ Using information } & Female & 149 & 94.94 & 14146.00 & \multirow{2}{*}{2971.000} & \multirow{2}{*}{.788} \\
\hline & Male & 41 & 97.57 & 3999.00 & & \\
\hline \multirow{2}{*}{$\begin{array}{l}\text { Designing and } \\
\text { implementing } \\
\text { experiments }\end{array}$} & Female & 149 & 96.42 & 14366.00 & \multirow[t]{2}{*}{2918.000} & \multirow[t]{2}{*}{.661} \\
\hline & Male & 41 & 92.17 & 3779.00 & & \\
\hline \multirow{2}{*}{$\begin{array}{l}\text { Use of the } \\
\text { scientific process } \\
\text { skills }\end{array}$} & Female & 149 & 95.49 & 14227.50 & \multirow[t]{2}{*}{3052.500} & \multirow[t]{2}{*}{.995} \\
\hline & Male & 41 & 95.55 & 3917.50 & & \\
\hline \multirow{2}{*}{$\begin{array}{l}\text { Research and } \\
\text { development }\end{array}$} & Female & 149 & 96.37 & 14358.50 & \multirow[t]{2}{*}{2925.500} & \multirow[t]{2}{*}{.675} \\
\hline & Male & 41 & 92.35 & 3786.50 & & \\
\hline \multirow[t]{2}{*}{ Total } & Female & 149 & 95.82 & 14276.50 & \multirow[t]{2}{*}{3007.500} & \multirow[t]{2}{*}{.880} \\
\hline & Male & 41 & 94.35 & 3868.50 & & \\
\hline
\end{tabular}

Table 5 shows that the scores of the participants for the scale as a whole and for the subdimensions of using information, designng and implementing experiments, using the scientific process skills and research and development do not significantly vary based on gender $\left(\mathrm{U}_{\mathrm{BD}}=2971.000, \mathrm{U}_{\mathrm{DTU}}=2918.000, \mathrm{U}_{\mathrm{BSB}}=3052.500, \mathrm{U}_{\mathrm{AG}}=2925.500, \mathrm{U}_{\mathrm{T}}=3007.500\right.$; $\mathrm{p}>.05)$. Therefore, it is safe to argue that gender has no significant effect on the use of ICT. 
In order to see whether or not the scores of the participants significantly vary based on the purpose of using the ICT the Kruskal Wallis H- Test was used. The results of the Kruskal Wallis H- Test are given in Table 6.

Table 6.

Results of the Kruskal Wallis H- Test

\begin{tabular}{|c|c|c|c|c|c|c|c|}
\hline $\begin{array}{l}\text { Sub- } \\
\text { dimensions }\end{array}$ & $\begin{array}{l}\text { Puspose of } \\
\text { using the ICT }\end{array}$ & $\mathrm{N}$ & $\begin{array}{c}\text { Rank } \\
\text { average }\end{array}$ & sd & $\mathrm{X}^{2}$ & $\mathrm{p}$ & $\begin{array}{c}\text { Significance } \\
\text { (Mann } \\
\text { Whitney) }\end{array}$ \\
\hline \multirow{4}{*}{$\begin{array}{l}\text { Using } \\
\text { information }\end{array}$} & Research & 36 & 91.28 & \multirow{4}{*}{3} & \multirow{4}{*}{1.225} & \multirow{4}{*}{.747} & \multirow{4}{*}{-} \\
\hline & Social Media & 73 & 101.01 & & & & \\
\hline & Communication & 49 & 91.89 & & & & \\
\hline & Fun & 32 & 93.20 & & & & \\
\hline \multirow{4}{*}{$\begin{array}{l}\text { Designing and } \\
\text { implementing } \\
\text { experiments }\end{array}$} & Research & 36 & 93.74 & \multirow{4}{*}{4} & \multirow{4}{*}{.919} & \multirow{4}{*}{.922} & \multirow{4}{*}{-} \\
\hline & Social Media & 73 & 98.25 & & & & \\
\hline & Communication & 49 & 96.85 & & & & \\
\hline & Fun & 32 & 92.03 & & & & \\
\hline \multirow{4}{*}{$\begin{array}{l}\text { Using the } \\
\text { scientific } \\
\text { process skills }\end{array}$} & Research & 36 & 90.51 & \multirow{4}{*}{3} & \multirow{4}{*}{.979} & \multirow{4}{*}{.806} & \multirow{4}{*}{-} \\
\hline & Social Media & 73 & 93.40 & & & & \\
\hline & Communication & 49 & 97.92 & & & & \\
\hline & Fun & 32 & 102.20 & & & & \\
\hline \multirow{4}{*}{$\begin{array}{l}\text { Research and } \\
\text { development }\end{array}$} & Research & 36 & 95.08 & \multirow{4}{*}{3} & \multirow{4}{*}{2.893} & \multirow{4}{*}{.408} & \multirow{4}{*}{-} \\
\hline & Social Media & 73 & 101.69 & & & & \\
\hline & Communication & 49 & 95.29 & & & & \\
\hline & Fun & 32 & 82.17 & & & & \\
\hline \multirow{4}{*}{ Total } & Research & 36 & 92.85 & \multirow{4}{*}{4} & \multirow{4}{*}{.655} & \multirow{4}{*}{.957} & \multirow{4}{*}{-} \\
\hline & Social Media & 73 & 98,20 & & & & \\
\hline & Communication & 49 & 95,91 & & & & \\
\hline & Fun & 32 & 94.16 & & & & \\
\hline
\end{tabular}

As can be seen in Table 6 the scores of the participants for the sub-dimension of using information do not significantly vary based on the purposes of using the ICT ( $p>0.05)$. On the other hand, it is found that the participants in this subdimension mostly used the ICT for social media and less used it for research. 
The scores of the participants for the sub-dimension of designing and implementing experiments do not significantly vary based on the purposes of using the ICT ( $p>.05)$. In addition, it is found that the participants in this subdimension mostly used the ICT for social media and less used it for entertainment purposes.

Table 6 also shows that the scores of the participants for the sub-dimension of using the scientific process skills do not significantly vary based on the purposes of using the ICT ( $p>$.05). It is seen that the participants in this subdimension mostly used the ICT for entertainment purposes and less used it for research purposes.

Table 6 also shows that the scores of the participants for the sub-dimension of research and development do not significantly vary based on the purposes of using the ICT ( $p>$.05). In addition, it is found that the participants in this subdimension mostly used the ICT for social media and less used it for entertainment purposes.

The total scores of the participants do not significantly vary based on the purposes of using the ICT ( $p>$.05). Their mean scores suggest that the participants use the ICT mostly for social media and less for research-related purposes.

\section{DISCUSSION, CONCLUSIONS AND SUGGESTIONS}

The findings of the study suggest that the mean score of the participants for the subdimension Using information is 4.29. It indicates that the participants always employ the ICT in using information. Their mean score for the sub-dimension of Research and development is found to be 4.35. It suggests that the participants always employ the ICT in the activities related to research and development. The mean scores of the participants in regard to the sub-dimensions Designing and implementing experiments and Using scientific process skills are 3.64 and 3.79, respectively. These findings indicate that the participants frequently make use of the ICT concerning the design and implementation of experiments and the scientific process skills. In addition, it is concluded that the pre-service science teachers participated in the study had the highest mean score in the research and development sub-dimension and the lowest mean in the experimental design and implementation sub-dimension. Therefore, it can be said that the pre-service science teachers use the information communication technologies in order to access the new or existing information in the scientific process. In addition to this, it can be stated that the pre-service science teachers participated in the study do not frequently prefer the information communication technologies in the experimental design stage which is the application of the theoretical knowledge. For instance, Önür (2007) concluded that $34,9 \%$ of the undergraduate students employed the ICT everyday to make research about several topics.

It is found that there is no statistically significant difference between the pre-service science teachers' use of ICT in scientific process based on their gender. Therefore, it can be said that all individuals regardless of their gender use the information communication technologies. This result can be attributed to the fact that individuals independent of their gender interact with the information communication technologies 
in their daily life. Similar findings are reported by various studies (i.e., Koszalka, 2000; Looker, \& Thiessen, 2003; Koca, 2006; Önür, 2007). However, there are some statistically insignificant differences concerning the sub-dimensions of the scale based on gender. For instance, the sub-dimension scores for the experimental design and implementation and for the sub-dimension of the research and development as well as total scores of the participants indicate that the female pre-service science teachers use the ICT more frequently than the male pre-service science teachers. Çavuş and Göktaş (2006) in their study on sample of the pre-service teachersconcluded that the female teacher candidates employed the information technology to access information more frequently than the male teacher candidates. Similarly, in their study, Akın and Baştuğ (2005) found that the female students used the information communication technologies for educational purposes more than the male students.

In the study it is also found that the use of the ICT by the participants does not significantly vary based on the purposes of using the ICT. The other findings of the study is that the pre-service science teachers mostly use the information communication technologies in scientific process for social media when examined in terms of the subdimensions of the using information, designing and implemeting experiments, research and development and in terms of the ICT total scores. Therefore, it is possible to state that individuals do more research by means of social media, and thus, they have reached new information through it. Among the reasons for this situation the use of the information and communication technologies for social media purposes can be given as why new or existing information can be reached through social media. The social media accounts used for scientific studies and courses can also be said to have an impact on this result. The findings suggest that based on the scores of the sub-dimension using the scientific process skills the pre-service science teachers participated in the study use the information communication technologies mostly for entertainment purposes. In addition, it was determined that the individuals mostly use the information communication technologies for communication purposes in their daily lives. Akkoyunlu (2002) concluded that science teachers mostly use the ICT for accessing and sharing information. Hack and Smey (1997) stated that pre-service teachers mostly used the Internet for the information access and communication purposes. Çavuş and Göktaş (2006) found similar results. However, Atav, Akkoyunlu and Sağlam (2006) concluded that only $23,6 \%$ of the pre-service teachers employed the ICT for making homework or accessing information.

Today, the fact that individuals live in the age of information and technology makes current use and effective use of information communication technologies mandatory. The most basic factors for the inclusion of individuals with these qualifications into society are seen as education and teacher. There is a limited number of studies examining the use of ICTs by pre-service science teachers. Therefore, it can be said that this research can contribute to the literature.

The following suggestions are developed in accordance with the findings obtained in the study: 
- Activities can be carried to reinforce and expand the use of the ICT by preservice science teachers.

- Seminars can be organized in order to enable the pre-service science teachers to make use of the information communication technologies for other areas than social media-related purposes.

- Activities can be organized at the teacher training programs for pre-service science teachers to gain knowledge and skills that will enable them to use the ICT effectively in scientific process.

- Teacher training programs may involve those courses and activities which contribute to the use of the ICT.

- Future studies may analyse the other factors that may have significant effects on the use of the ICT.

- This study was carried out on a sample of the pre-service science teachers attending a university in the western part of Turkey, and therefore, it is limited in scope. Thus, similar studies can be done with different participant groups in future.

\section{References}

Açıkgül Fırat, E., \& Özden, M. (2015). Öğretmen adaylarının bilimsel süreçte bilgi iletişim teknolojileri kullanımına yönelik ölçek geliştirilmesi. Gazi Üniversitesi Gazi Eğitim Fakültesi Dergisi, 35(1), 1-25.

Akın, M., \& Baştuğ, A. (2005). Erzincan eğitim fakültesi ilköğretim bölümü sınıf öğretmenliği anabilim dalı öğrencilerinin bilgisayar ve internet teknolojilerinden yararlanma düzeylerini belirlemeye yönelik bir ön araştırma. Erzincan Eğitim Fakültesi Dergisi, 7(1), 47-58.

Akkoyunlu, B. (2002). Öğretmenlerin internet kullanımı ve bu konudaki öğretmen görüşleri. Hacettepe Üniversitesi Ĕ̆itim Fakültesi Dergisi, 2, 1-8.

Albayrak Sarı, A., Canbazoğlu Bilici, S., Baran, E., \& Özbay, U. (2016). Farklı branşlardaki öğretmenlerin teknolojik pedagojik alan bilgisi (tpab) yeterlikleri ile bilgi ve iletişim teknolojilerine yönelik tutumları arasındaki ilişkinin incelenmesi. Eğitim Teknolojisi Kuram ve Uygulama Dergisi, 6(1), 1-21.

Atav, E., Akkoyunlu, B., \& Sağlam, N. (2006). Öğretmen adaylarının internete erişim olanakları ve kullanım amaçları. Hacettepe Üniversitesi Eğitim Fakültesi Dergisi, 30(30), 37-44.

Büyüköztürk, Ş., Kılıç Çakmak, E., Akgün, Ö. E., Karadeniz, Ş., \& Demirel, F. (2012). Bilimsel araştırma yöntemleri. Ankara: Pegem A Yayıncılık.

Cüre, F., \& Özdener, N. (2008). Öğretmenlerin bilgi ve iletişim teknolojileri (BİT) uygulama başarıları ve BİT’e yönelik tutumları. Hacettepe Üniversitesi Eğitim Fakültesi Dergisi, 34, 41-53.

Çavaş, B., \& Çavaş, P. H. (2005). Teknoloji tabanlı öğrenme: Roboticsclub. Akademik Bilişim Konferansı. Gaziantep Üniversitesi, Gaziantep.

Çavuş, H., \& Göktaş, İ. (2006). Eğitim fakültesinde öğrenim gören öğrencilerin internetten yararlanma nedenleri ve kazanımları. Yüzüncü Yıl Üniversitesi, Eğitim Fakültesi Dergisi, 3(2), 56-78. 
Demiralay, R., \& Karadeniz, Ş. (2010). Bilgi ve iletişim teknolojileri kullanımının, ilköğretim öğretmen adaylarının bilgi okuryazarlığı öz-yeterlik algılarına etkisi. Kuram ve Uygulamada Eğitim Bilimleri, 10(2), 819-851.

Demiraslan, Y., \& Usluel, Y. K. (2005). Bilgi ve iletişim teknolojilerinin öğrenme öğretme sürecine entegrasyonunda öğretmenlerin durumu. The Turkish Online Journal of Educational Technology, 4(3), 15.

Ersoy, A., \& Türkkan, B. (2009). İlköğretim öğrencilerinin resimlerinde internet algısı. Illköğretim Online, 8(1), 57-73

Eryılmaz, S. (2018). Öğrencilerin bilgi ve iletişim teknolojileri yeterliliklerinin belirlenmesi: gazi üniversitesi, turizm fakültesi örneği. Electronic Journal of Social Sciences, 17(65), 37-49.

Hack, L., \& Smey, S. (1997). A survey of internet usebyteachers in three urban connecticut schools. School Library Media Quarterly, 25(3), 151-55.

Hazzan, 0., (2000). Attitudes of prospective high school mathematics teacher towards integrating information technologies in their future teaching. Proceedings of Information Technology and TeacherEducation International Conference, 1(3), 1582-1587.

ISTE - International Societyfor English in Education. (2000). NETS-standardsfor teachers. Washington DC: ISTE.

Jang, S. J. (2009). Exploration of secondary students' creativitybyintegrating web-based technology into an innovative science curriculum. Computers \& Education, 52, 247255.

Koca, M. (2006). Bilgi ve iletişim teknolojileri kabul ve kullanımı birleștirilmiş modelinin değişkenlerine gore öğretmenlerin bilgi ve iletişim teknolojilerini kullanımlarının incelenmesi. Yayımlanmamış Yüksek Lisans Tezi, Hacettepe Üniversitesi, Fen Bilimler Enstitüsü. Ankara.

Koszalka, T. A. (2000). Effect of computer_mediated communications on teachers' attitudes toward using web resources in the classroom. Journal of Instructional Psychology, 28(2), 95103

Looker, E. D., \& Thiessen, V. (2003) Beyond the digital divide in Canadian schools: Fromaccess to competency in theuse of information technology. Social Science ComputerReview, 21(4), 47590.

Milli Eğitim Bakanlı̆̆ı [MEB]. (2006). İlköğretim bilgisayar dersi öğretim programı (1-8. Sınıflar). Talim Terbiye Kurulu: Ankara.

Milli Eğitim Bakanlığı [MEB]. (2017). İlköğretim fen bilimleri dersi öğretim programı (5-8. Sinıflar). Talim Terbiye Kurulu: Ankara.

Önür, N. (2007). Dijital bölünme ve gençlik: bilgi toplumunun sınırlarında erişilen toplumsallık. Sosyoloji Dergisi, 17, 195-233.

Slough, S. W., \& Chamblee, G. E. (2000). Implementing technology in secondary science and mathematics classrooms. Proceedings of Information Technology and Teacher Education International Conference, 1(3), 1021-1026.

Şad, S. N., \& Nalçacı, Ö. İ. (2015). Öğretmen adaylarının eğitimde bilgi ve iletişim teknolojilerini kullanmaya ilişkin yeterlilik algıları. Mersin Üniversitesi Eğitim Fakültesi Dergisi, 11(1), 177197.

Tor, H., \& Erden, O. (2004). İlköğretim öğrencilerinin bilgi teknolojilerinden yararlanma düzeyleri üzerine bir araştırma. TheTurkish Online Journal of Educational Technology, 3(1), 16. 
UNESCO. (2006). Using ICT to Develop Literacy. Bangkok: UNESCO.

Usluel, Y. K., Mumcu, F. K., \& Demiraslan Y. (2007). Öğrenme-öğretme sürecinde bilgi ve iletişim teknolojileri: Öğretmenlerin entegrasyon süreci ve engelleriyle ilgili görüşleri. Hacettepe Üniversitesi Eğitim Fakültesi Dergisi, 32, 164-179.

Ural, A. (2015). Ortaokul matematik öğretmenlerinin bilgi iletişim teknolojisi ve psikomotor beceri kullanımlarının incelenmesi. TurkishJournal of Computer and Mathematics Education, 6(1), 93-116. 